\title{
Ameliorative Effect of Zingiber officinale on Chemical Induced DNA Damage in Rats Using PCR Analysis
}

\author{
Mary Abiola Okesola ${ }^{1, *(D)}$, Olubanke Ogunlana ${ }^{1}$, Israel Afolabi ${ }^{1}$, Amos Onasanya ${ }^{2}$ \\ 1 Department of Biochemistry, Covenant University, Ota, Nigeria \\ 2 Department of Chemical Sciences, Biochemistry Programme, Afe Babalola University, Ado-Ekiti, Nigeria \\ * Correspondence: okesolaabiola@yahoo.com;
}

Scopus Author ID 57200559627

Received: 12.11.2020; Revised: 5.12.2020; Accepted: 6.12.2020; Published: 9.12.2020

\begin{abstract}
Ginger rhizomes have been reportedly used in folk medicine for the management of various ailments. This study, therefore, investigates the ameliorative effect of the ethanolic extract of ginger (Zingiber officinale) rhizomes against DNA damage in rats induced with different carcinogens. Fifteen Wistar rats grouped into 3 of 5 rats per group were used for the study. The first set of blood samples was first collected before the animals were orally treated with heavy metals. After 14 days of induction, the second set of blood was collected. The third phase of blood collection was done after administering an ethanolic extract of $Z$. officinale for 14 days. The UV wavelength absorption spectrum and conventional PCR analysis were carried out on DNA extracts of all the animals. Cluster analysis of optical density (OD) and PCR data were carried out as well as genomic instability, similarity, and diversity using the best 3 Random Amplified Polymorphic DNA (RAPD) primers. The PCR -DNA concentration analysis showed the Z. officinale extract's ameliorative effect against lead acetate, cadmium chloride, and arsenic trioxide-induced DNA damage with a significant $(\mathrm{p}<0.05)$ reduction in DNA concentration of the treated rats when compared with induced rats. The cluster analysis of optical density values revealed close similarity between the control animals' DNA, a slight similarity with treated animals' DNA, and a significant difference with the induced animal DNA. These results indicated the ameliorative properties of $Z$. officinale against these heavy metals induced DNA damage in rats.
\end{abstract}

Keywords: Zingiber officinale; polymerase chain reaction; RAPD- PCR Primer; heavy metals.

(0) 2020 by the authors. This article is an open-access article distributed under the terms and conditions of the Creative Commons Attribution (CC BY) license (https://creativecommons.org/licenses/by/4.0/).

\section{Introduction}

Deoxyribonucleic acid (DNA) is an essential molecule that maintains the genetic information of all living organisms [1]; hence, maintaining healthy DNA is paramount to the proper functioning of all metabolic processes occurring in the living system. Several studies involved heavy metals as one of the foremost cause of DNA damage due to the generation of reactive oxygen species, which causes changes in metabolism leading to lipid peroxidation, depletion of sulphydryls, a break in DNA strand, a base missing from the backbone of DNA, or a chemically changed base, such as 8-hydrodeoxyguanosine (8-OHdG), which is a significant marker of oxidative stress $[2,3,4]$. Thus damaged DNA may induce several cellular adverse responses on the cell such as triggering apoptotic pathways, cardiovascular disease, and necrosis [5, 6, 7]. Rajkumar et al. [8] revealed that heavy metals are unavoidable because of man's anthropogenic activity that can increase its content in the air, water, soil, and tissues of living organisms leading to health implications in the human system. According to Oyinloye 
et al. [9] and Ojo et al. [4], cadmium, lead, and arsenic are the most commonly found heavy metals in the surroundings, which cause risks for human health and the environment. The findings of [10] revealed that exposure to $\operatorname{DMBA}(7,12$, -dimethyl benz[a] anthracene) is a major cause of pulmonary injury due to oxidative stress induced by this compound in experimental rats. Research conducted by Skipper et al. [11] showed that cadmium produces various genotoxic effects such as DNA damage and chromosomal aberrations. Ebmeyer et al. [12] revealed the toxicity of arsenic by inducing superoxide $\left(\mathrm{O}_{2}\right)$, a hindrance to various cell signaling pathways resulting in the subsequent production of $\mathrm{H}_{2} \mathrm{O}_{2}$ and $\mathrm{OH}$ radicals causing DNA damage, altering of the antioxidant enzymes' capacity, and generation of lipid peroxide. However, the ginger solution at $160 \mathrm{mg} / \mathrm{kg}$ body weight was administered orally to rats induced with cadmium to ameliorate this effect.

In the same way, [13] emphasized the potent value of ginger for various ailments in different parts of the world to treat diarrhea, stomach upset, nausea, and indigestion. Furthermore, [14] reported ginger and turmeric as a protective measure in preventing male infertility. Okesola et al. [15] reported the neuromodulatory effects of ethyl acetate fraction of Zingiber officinale Roscoe to extract in rats with lead-induced oxidative stress as well as the protective role of Zingiber officinal on selected biochemical indices and cytogenic studies in rats induced with lead [16]. However, many researchers have been carried out on the hazardous effect of these three metals. Its damaging effect on DNA and ameliorative potential of ginger rhizome on the damaged DNA by these metals employing PCR analysis has not been extensively reviewed.

\section{Materials and Methods}

\subsection{Chemicals used.}

Chemicals used were of analytical grades and prepared via sterilized distilled water. The lead was obtained as lead acetate, arsenic as arsenic trioxide, and cadmium as cadmium chloride. These three metals were obtained from Sigma and were used as a toxicant to induced DNA damage in experimental animals.

\subsection{Plant material.}

Zingiber officinale tuber was obtained from Oja Oba in Ado Ekiti, Ekiti State, Nigeria. After authentication and documentation at the herbarium section of the Ekiti State University, the tuber's peeling was done, sliced, rinsed, and air-dried by spreading in a well-ventilated environment. It was then pulverized into powdered form and kept in a closed jar.

\subsection{Preparation of ethanolic extract of Zingiber officinale.}

80 grams of powdered Zingiber officinale was macerated in a solution of $600 \mathrm{ml}$ of $95 \%$ ethanol. This was allowed to stand for 72 hours with intermittent shaking. The mixture was separated using Whatman's paper. After that, it dried completely using a rotary evaporator. The residue obtained was kept for further analysis. The extract obtained was prepared at a 50 $\mathrm{mg} / \mathrm{ml}$ concentration and administered via oral gavage at a dosage of $200 \mathrm{mg} / \mathrm{kg}$ body weight following the procedure described in the studies reported by $[17,18,19]$. 


\subsection{Animals and experimental protocol.}

Fifteen Wistar rats weighing between 180-240 g were purchased from the central animal house of Afe Babalola University, Ado-Ekiti. The animals were housed in cages in the Departmental animal house at room temperature with free access to clean water and standard pelleted feed. Following the rule and regulation of the animal ethical committee with approval number ABUADSCI/1009. They were acclimatized for 2 weeks, after which the first blood sample was collected.

\subsection{Grouping of the animals and induction of the metals.}

The fifteen Wistar rats were divided into three groups consisting of five rats in each group. Lead acetate, arsenic trioxide, and cadmium chloride were dissolved separately in distilled water at a concentration of $50 \mathrm{mg} / \mathrm{ml}$, and animals in each group were induced daily for 14 days by oral gavage via cannula with the same dose $(10 \mathrm{mg} / \mathrm{kg})$ following the method of [20]. Group 1, 2, and 3 were induced with lead acetate, arsenic trioxide, and cadmium chloride, respectively, and the second set of blood samples was collected after 14day administration of these three metals.

\subsection{Administration of plant extract.}

The administration of Zingiber officinale extract commences immediately after the second blood collection, and the extract was administered at a dose of $200 \mathrm{mg} / \mathrm{kg}$ body weight following the method of $[17,18,19]$. After 14 days of treatment, the final blood sample was collected for further analysis.

\subsection{DNA extraction and purification.}

DNA extraction and purification from the fresh frozen blood samples of the experimental animals before induction, after induction, and after treatment was achieved via Zymo research kits supplied by Inqaba Biotec, South Africa. The set of primers selected and used are (OPB-8, OPB-12, and OPT-16) for PCR fingerprint analysis on the extracted DNA. PCR reactions were done in a $12.5 \mu \mathrm{l}$ reaction volume containing $2.5 \mu \mathrm{l}$ of template DNA solution in which $0.2 \mu \mathrm{l}$ of DNA Taq polymerase, $1.25 \mu \mathrm{l}$ Taq buffer, $1.0 \mu \mathrm{MgCl} 2,1.25 \mu \mathrm{l}$ diluted dATP, dGTP, dCTP, dTTP (deoxynucleotides) was added after the dilution of dNTP with deionized water, and $1.25 \mu 1$ Tween 20 (5\%), $0.5 \mu \mathrm{l}$ of each of diluted primers, and 4.05 $\mu \mathrm{l}$ of double distilled water respectively. This was followed by a PCR amplification reaction via Masteral Thermal Cycler (Corbett Research Canada). The cycling parameters were $94{ }^{\circ} \mathrm{C}$, for $3 \mathrm{~min}$ and 35 cycles to denature the DNA at $94^{\circ} \mathrm{C}, 1 \mathrm{~min}$; annealed at $55^{\circ} \mathrm{C}$ for $1 \mathrm{~min}$ and extend at $72{ }^{\circ} \mathrm{C}$, for $2 \mathrm{~min}$. The amplification products were separated on the $0.8 \%$ agarose gel for $1-2 \mathrm{~h}$ at $100 \mathrm{~V}$, and recorded with the Alpha digital imager gel documentation system (Alpha Innotech, Canada) after staining with G-green dye $(0.5 \mu \mathrm{g} / \mathrm{ml})$. All tests were carried out in duplicates [21].

\subsection{PCR (DNA) product solution preparation for UV spectrophotometer.}

PCR (DNA) product $(10 \mu \mathrm{l})$ was added to $990 \mu \mathrm{l}$ distilled water, mixed. The absorbance value was taken from A200-A960 UV wavelengths via Spectronic 20 spectrophotometer. The results obtained were expressed as the concentration of RAPD -PCR values. 


\subsection{Generation of clusters using optical density $(O D)$ data values.}

The OD data were first converted to pairwise distance matrices using the Jaccard coefficient of similarity (Ivchenko and Honov, 1998) present in NTSYS-PC 2.1, and the dendrogram cluster was created by Unweighted Pair Group Method with Arithmetic mean (UPGMA) [22].

\subsection{Data analysis.}

Data analyses were carried out with the one-way analysis of variance (ANOVA) using the SPSS software package for Windows (version 20.0). Whenever a significant difference was detected, post-hoc testing was performed for inter-group comparisons using Tukey's multiple comparisons test. Results are expressed as mean \pm standard deviation (SD) for five determinations $(n=5)$, and $p$ values $<0.05$ were considered statistically significant.

\section{Results and Discussion}

\subsection{Effect of heavy metals on body weight.}

There were variations in the rats' body weights before induction of heavy metals compared with the weight after induction and after administration of Zingiber officinale (Figure 1). There was a significant reduction $(p<0.05)$ in the body weight of rats induced with cadmium chloride when compared to the rat's weight before induction (control) and after treatment. The changes in weight of rats induced with lead acetate and arsenic trioxide are not statistically significant compared with that of cadmium chloride.

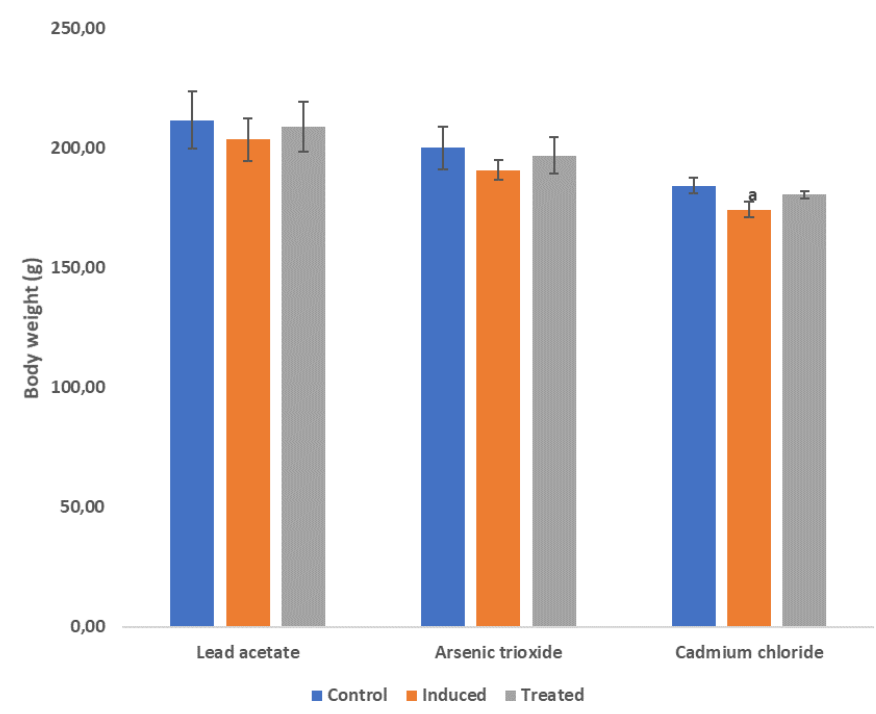

Figure 1. Body weights $(\mathrm{g})$ of rats before and after heavy metal administration and after treatment with ethanolic extract of Zingiber officinale.

Values are expressed as Mean $\pm \mathrm{SD}, \mathrm{n}=5$.

${ }^{\mathrm{a}} \mathrm{p}<0.05$ when compared to the control group

\subsection{Effect of heavy metals on DNA fingerprints of the rats as revealed by PCR analysis.}

The results of the best three primers (OPB-08, OPB-12 \& OPT-16) of RAPD PCR fingerprinting analysis amplification for the control induced and treated RAPD-PCR revealed the appearance and disappearance of the band patterns. The gel photograph showed different 
band patterns in each rat sample compared to the band obtained before induction with heavy metals, after induction, and after treatment with Zingiber officinale. Appearances of new bands were observed in heavy metal-induced rat samples. Some of these newly formed bands disappeared while some faded when it was treated with Zingiber officinale (Figures 2, 3 and 4). Primer OPB - 12 displayed more visible and reproducible bands than the other primers.

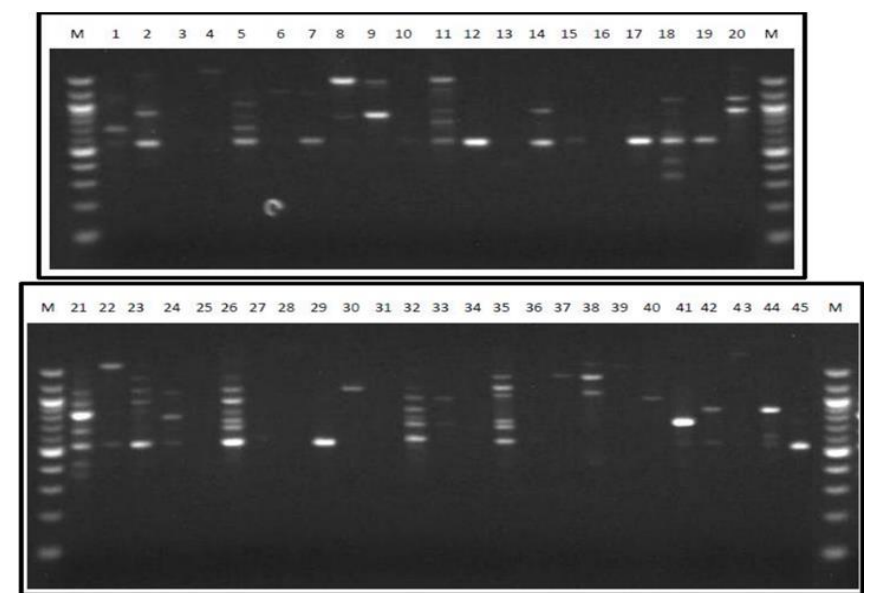

Figure 2. OPB-08 RAPD PCR fingerprint differentiating control induced and treated rats DNA. M = Marker, 1 to 45 represent the fifteen albino rats used for the analysis at three different treated stages (control induced and treated). Numbers $1,4,7,10,13,16,19,22,25,28,31,34,37,40$ and 43 represent control DNA samples of the

fifteen Rats (From rat 1 to 15); Numbers 2, 5, 8, 11, 14, 17, 20, 23, 26, 29, 32, 35, 38, 41, and 44 represent induced DNA samples of all the fifteen rats; Numbers 3, 6, 9, 12, 15, 18, 21, 24, 27, 30, 33, 36, 39, 42 and 45 represent treated DNA samples of all the fifteen rats.

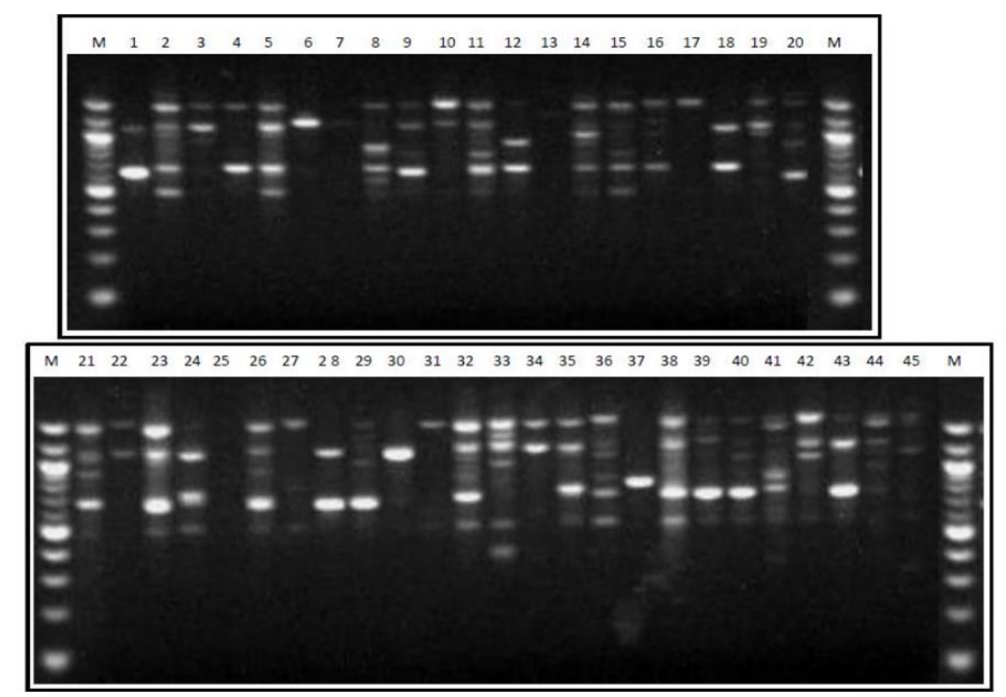

Figure 3. OPB-12 RAPD PCR fingerprint differentiating control, induced, and treated rat DNA. M = Marker, 1 to 45 represent the fifteen albino rats used for the analysis. Numbers $1,4,7,10,13,16,19,22,25,28,31,34$, 37, 40 and 43 represent control DNA samples of the fifteen Rats (From rat 1 to 15); Numbers 2, 5, 8, 11, 14, 17, $20,23,26,29,32,35,38,41$, and 44 represent induced DNA samples of all the fifteen rats; Numbers 3, 6, 9, 12, $15,18,21,24,27,30,33,36,39,42$ and 45 represent treated DNA samples of all the fifteen rats.

\subsection{Cluster analysis and phylogenetic relationship.}

Phylogenetic relationship was established from the cluster analysis of the optical density (OD). From the Gel photograph analysis, the band's presence was scored 1, whereas the absence of the band was scored 0 . The scored markers were converted into a binomial $(0 / 1)$ matrix. Based on the matrices dendrogram, clusters were created by Unweighted Pair Group Method with Arithmetic mean (UPGMA). The dendrogram was constructed for each PCR DNA product of each primer. Then a pooled dendrogram was also constructed to show the 
relationship between controls, induced, and treated DNA (Figures 5, 6, 7, and 8). The three dendrograms generated from the three primers used revealed a similar correlation between the control PCR-DNA samples and treated samples while the induced PCR-DNA samples bunched together in a group differentiating themselves from the control and treated PCR-DNA samples. This was also the case in the results obtained from pooled RAPD-PCR in the three dendrograms generated.

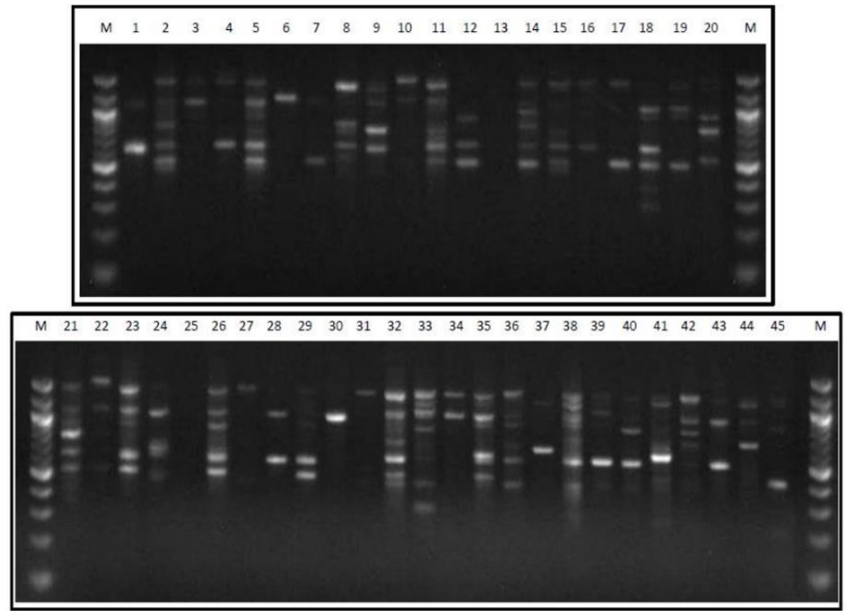

Figure 4. OPT-16 RAPD PCR fingerprint differentiating control, induced and treated rat DNA. $M=$ Marker, 1 to 45 represents the fifteen albino rats used for the analysis. Numbers 1, 4, 7, 10, 13, 16, 19, 22, 25, 28, 31, 34, 37, 40 and 43 represent control DNA samples of the fifteen Rats (From rat 1 to 15); Numbers 2, 5, 8,11, 14, 17, $20,23,26,29,32,35,38,41$, and 44 represent induced DNA samples of all the fifteen rats; Numbers 3, 6, 9, 12, $15,18,21,24,27,30,33,36,39,42$ and 45 represent treated DNA samples of all the fifteen rats.

DNA damage is characterized by the appearance and disappearance of bands, an elevated level of oxidative stress, a decrease in the level of antioxidant defenses, and the generation of high lipid peroxides [23]. This study evaluates the ameliorative effect of ethanolic extract of Zingiber officinale against heavy metal-induced DNA damage. The relatively lower final body weight of induced rats may result from imbalance metabolism produced by impairment of zinc status in zinc-dependent enzymes, which are essential for many metabolic processes. This finding agrees with the finding of Seddik et al. [24] on the effect of lead acetate on body weight gain, food intake, and feed efficiency of the experimental rat.

Polymerase chain reactions are powerful tools for phylogenetic studies and in surveying genomic DNA to detect various types of damages [25]. In this study, damage induced by heavy metals on DNA was reflected by changes in PCR profile of the three primers used (OPB-08, OPB-12 \& OPT-16). This was reflected by genomic instability, similarity, and diversity that occurred after induction of heavy metals and after treatment with Zingiber officinale, which corroborates with that of Omar et al. [26] and Osman et al. [27]. In the amplification power of RAPD-PCR in detecting the genetic effect of the three heavy metals damage as reflected in DNA fingerprint bands, the interaction of lead acetate, arsenic trioxide, and cadmium chloride with DNA could be the reason for alteration in the structure and function of DNA including DNA adducts and breakage which was translated into appearance or disappearance of bands as well as variations in band intensities in the fingerprinting profile which was in line with the study of Noel and Rath [28] in which appearance and disappearance of bands represent damage in the DNA profile.

The genotoxic effects of these three heavy metals on rat's DNA were further evaluated using cluster analysis compared to DNA samples and the PCR product in each rat among control, induced, and treated DNA samples. The phylogenetic tree revealed polymorphism in 
forming clusters among the control of DNA extracts, induced, and treated DNA group. However, some differences in some induced rats' positioning were observed, corroborating that of [29]. There was a similarity between the control groups and the treated groups with a significant difference compared with the induced groups.

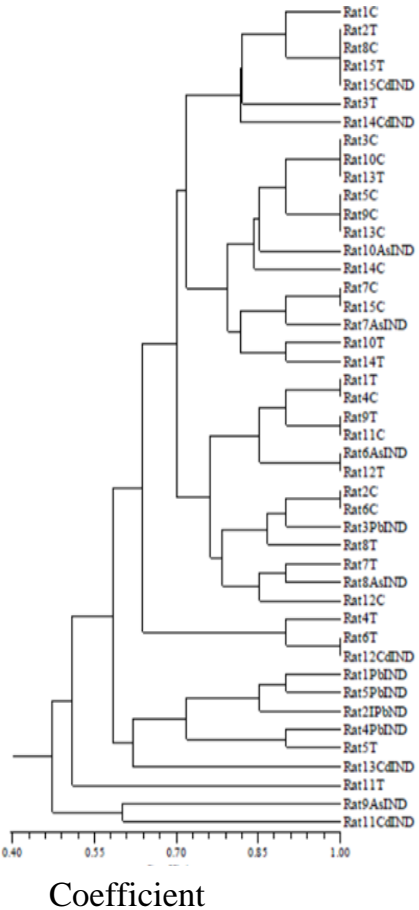

a: Numeric Data

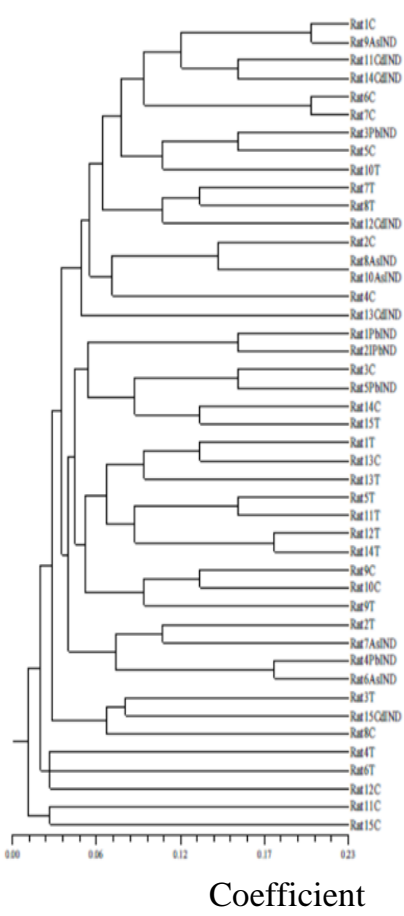

b: OD Value Data

Figure 5. OPB-8 RAPD PCR dendrogram cluster showing the relationship between controls, induced, and treated rats DNA.

Legend: RatT $=$ Rats treated with Zingiber officinale, $\mathrm{RatC}=\mathrm{Control}$ rats, $\mathrm{RatPb} \mathrm{IND}=$ Rats induced with lead acetate, Rat As= Rats induce with arsenic trioxide, and $\mathrm{RatCd}=\mathrm{Rats}$ induced with cadmium chloride.

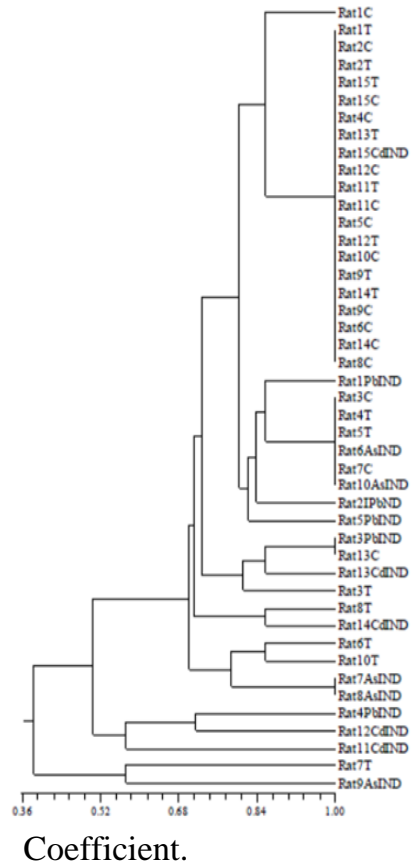

a: Numeric Data

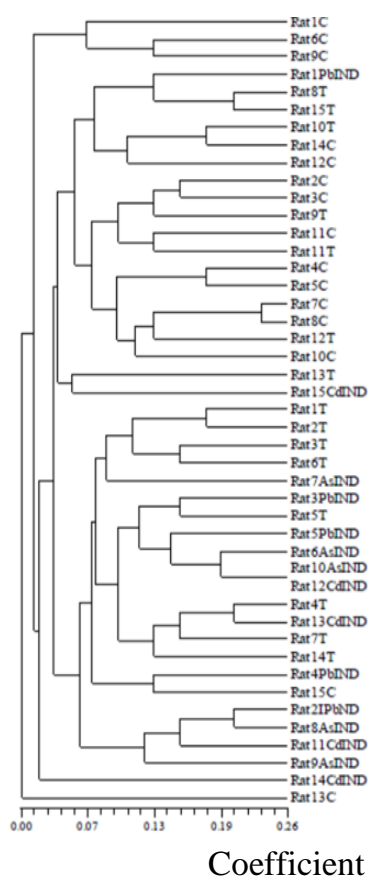

b: OD Value Data

Figure 6. OPB-12 RAPD PCR dendrogram cluster showing relationship between controls induced and treated rat's DNA.

Legend: $\mathrm{Rat} T=$ Rats treated with Zingiber officinale, $\mathrm{RatC}=\mathrm{Control}$ rats, $\mathrm{RatPb} \mathrm{IND}=$ Rats induced with lead acetate, Rat As= Rats induce with Arsenic trioxide, and $\mathrm{RatCd}=\mathrm{Rats}$ induced with Cadmium chloride. 


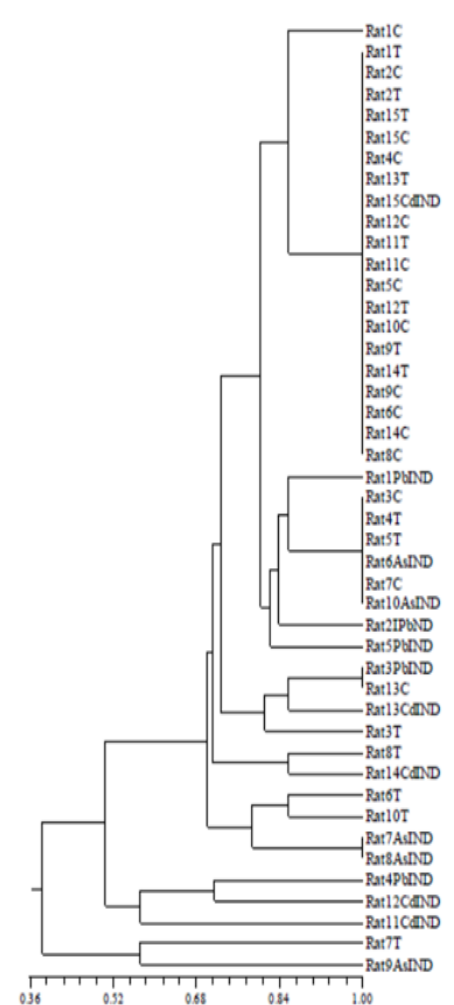

Coefficient

a: Numeric Data

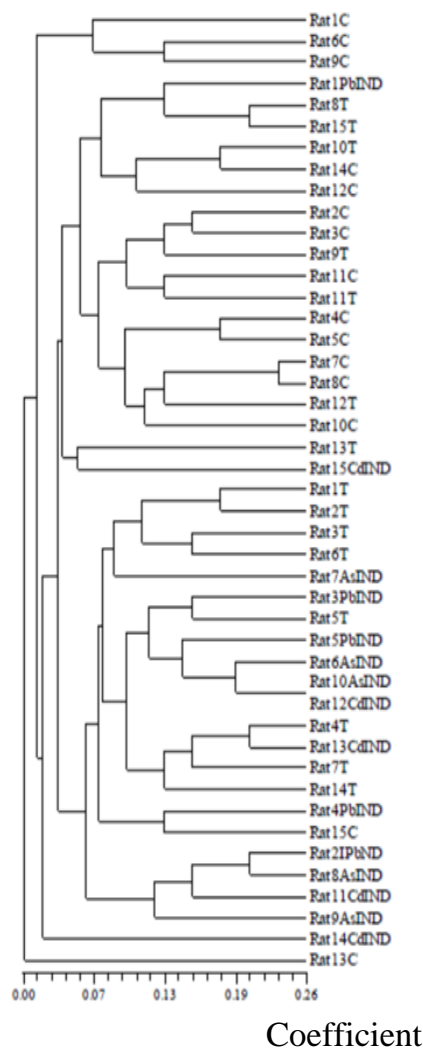

b: OD Value Data

Figure 7. OPT-16 RAPD PCR dendrogram cluster showing the relationship between controls induced and treated rat's DNA.

Legend: RatT $=$ Rats treated with Zingiber officinale, RatC $=$ Control rats, $\mathrm{RatPb} \mathrm{IND}=$ Rats induced with lead acetate, Rat $\mathrm{As}=$ Rats induce with Arsenic trioxide, and RatCd= Rats induced with Cadmium chloride.

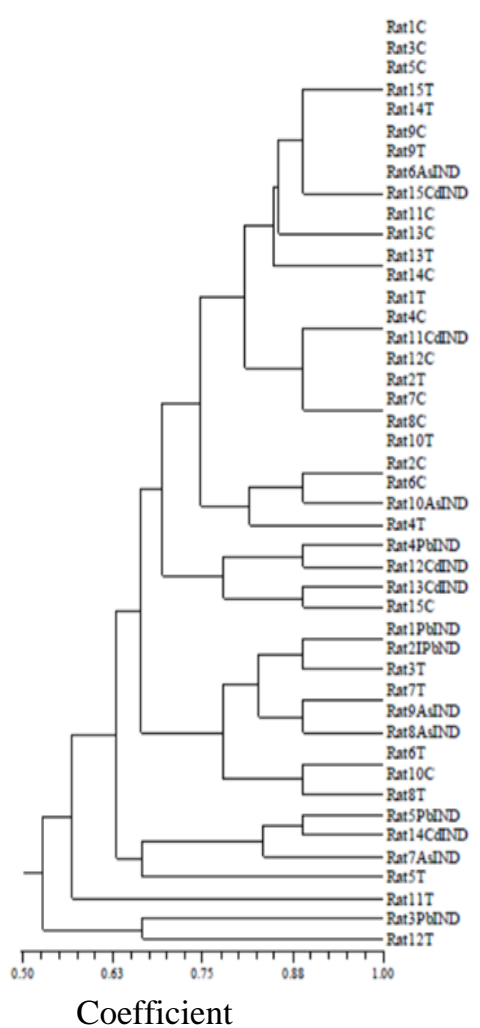

a: Numerical Data

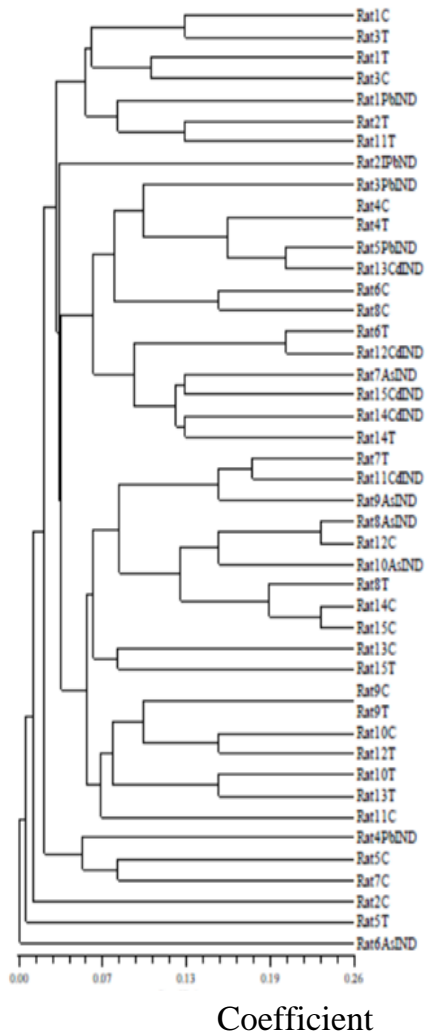

b: OD Value Data

Figure 8. Pooled RAPD PCR Dendrogram cluster showing relationship between controls, induced and treated DNA.

Legend: RatT $=$ Rats treated with Zingiber officinale, RatC $=$ Control rats, $\mathrm{RatPb} \mathrm{IND}=$ Rats induced with lead acetate, Rat As= Rats induce with Arsenic trioxide, and RatCd= Rats induced with Cadmium chloride. 


\section{Conclusions}

This study showed the damaging effect of heavy metals on DNA of the experimental rats. It revealed the potential of ethanolic extract of Zingiber officinale in ameliorating the adverse effect of these heavy metals as shown by PCR- DNA profiles, RAPD-PCR results, and phylogenic tree.

\section{Funding}

This research received no external funding.

\section{Acknowledgments}

This research has no acknowledgment.

\section{Conflicts of Interest}

The authors declare no conflict of interest. The funding organization(s) played no role in the study design; in the collection, analysis, and interpretation of data; in the report's writing; or in the decision to submit the report for publication.

\section{References}

1. Su, L.-J.; Zhang, J.-H.; Gomez, H.; Murugan, R.; Hong, X.; Xu, D.; Jiang, F.; Peng, Z-Y. Reactive oxygen species-induced lipid peroxidation in apoptosis, autophagy, and ferroptosis. Oxidative Medicine and Cellular Longevity 2019, 2019, https://doi.org/10.1155/2019/5080843.

2. Chang, H.; Yuan, W.; Wu, H.; Yin, X.; Xuan, H. Bioactive components and mechanisms of Chinese poplar propolis alleviates oxidized low-density lipoprotein-induced endothelial cells injury. BMC Complementary and Alternative Medicine 2018, 18, https://doi.org/10.1186/s12906-018-2215-8.

3. Ojo, O.A.; Ojo, A.B.; Osukoya, O.A.; Ajiboye, B.O. Aqueous Extract of Carica papaya Linn Roots Halts Sodium Arsenite-induced Renal Inflammation through inhibiting Adenosine deaminase, 8-Hydroxy-2'deoxyguanosine, C-Reactive Protein and inducible Nitric Oxide Synthase activity. Serbian J Exp Clin Res 2017, 18, 323-330, https://doi.org/10.1515/sjecr-2017-0029.

4. Ojo, O.A.; Ojo, A.B.; Awoyinka, O.A.; Olayide, I.; Ajiboye, B.O.; Oyinloye, B.E.; Osukoya, O.A.; Ibitayo, A.O. Aqueous extract of Carica papaya Linn roots potentially attenuates Arsenic induced biochemical and genotoxic effects in Wistar rats. $J$ Trad compl Med 2018, 8, 324-334, https://doi.org/10.1016/j.jtcme.2017.08.001.

5. Yang, H.; Tian, T.; Wu, D.; Guo, D.; Lu, J. Prevention and treatment effects of edible berries for three deadly diseases: cardiovascular disease, cancer and diabetes. Critical Reviews in Food Science and Nutrition 2019; 59, 1903-1912, https://doi.org/10.1080/10408398.2018.1432562.

6. Ojo, O.A.; Ojo, A.B.; Nwonuma, C.O.; Awakan, O.J.; Maimako, R.F.; Afolabi, B.L.; Taiwo, O.A. Puerarin: A Review on the Pharmacological Activity, Chemical Properties and Pharmacokinetics of Main Isoflavonoid. The Natural Products Journal 2020a, https://doi.org/10.2174/2210315510999201105145149.

7. Freitas, A.A.; de Magalhães, J.P. A review and Appraisal of the DNA Damage Theory of Ageing. Mutat Res 2011, 728, 12-22, https://doi.org/10.1016/j.mrrev.2011.05.001.

8. Rajkumar, M.; Prasad, M.N.; Swaminathan, S.; Freitas, H. Climate Change Driven Plant-metal-microbe Interactions. Environ Int 2013, 53, 74-86, https://doi.org/10.1016/j.envint.2012.12.009.

9. Oyinloye, B.E.; Ajiboye, B.O.; Ojo, O.A.; Musa, H.M.; Onikanni, S.A.; Ojo, A.A. Ameliorative potential of Aframomum melegueta extract in cadmium-induced hepatic damage and oxidative stress in male Wistar rats. J Appl Pharma Sci 2016, 6, 94-99, https://doi.org/10.7324/JAPS.2016.60714.

10. Dosumu, O.; Rotimi, S.O.; Akintunde, J.; Adeleye, O.O.; Sani, O.L.; Omotosho, O.O.; Osinuga, K.T.; Taiwo, O.A.; Ojo, O.A. Effects of vitamin K dietary supplementation in pulmonary dysfunction induced by 7, 12, -dimethyl benz[a] anthracene in rat. Journal of Biochemical and Molecular Toxicol 2020, https://doi.org/10.1002/jbt.22584.

11. Skipper, A.; Sims, J.N.; Yedjou, C.G.; Tchounwou, P.B. Cadmium chloride induces DNA Damage and Apoptosis of Human Liver Carcinoma Cells via Oxidative Stress. Int J Environ Res Public Health 2016, 13, https://doi.org/10.3390/ijerph13010088. 
12. Ebmeyer, J.; Rasinger, J.D.; Hengstler, J.G.; Schaudien, D.; Creutzenberg, O.; Lampen, A.; Braeuning, A.; Hessel-Pras, S. Hepatotoxic pyrrolizidine alkaloids induce DNA damage response in rat liver in a 28-day feeding study. Arch Toxicol 2020, 94, 1739-1751, https://doi.org/10.1007/s00204-020-02779-2.

13. Li, H.; Liu, Y.; Luo, D.; Ma, Y.; Zhang, J.; Li, M.; Yao, L.; Shi, X.; Liu, X.; Yang, K. Ginger for health care: An overview of systematic reviews. Complement. Ther. Med 2019, 45, 114-123, https://doi.org/10.1016/j.ctim.2019.06.002.

14. Akinyemi, A.J.; Thome, G.R.; Morsch, V.M.; Stefanello, N.; Goularte, J.F.; Belló-Klein, A.; Oboh, G.; Schetinger, M.R.C. Effect of dietary supplementation of ginger and turmeric rhizomes on angiotensin-1 converting enzyme (ACE) and arginase activities in L-NAME induced hypertensive rats. Journal of Functional Foods 2015, 17, 792-801, https://doi.org/10.1016/j.jff.2015.06.011.

15. Okesola, M.A.; Ajiboye, B.O.; Oyinloye, B.E.; Ojo, O.A. Neuromodulatory effects of ethyl acetate fraction of Zingiber officinale Roscoe extract in rats with lead-induced oxidative stress. Journal of Integrative Medicine 2019, 17, 125-131, https://doi.org/10.1016/j.joim.2019.01.002.

16. Okesola, M.A.; Ajiboye, B.O.; Oyinloye, B.E.; Ojo, O.A. Effect of Zingiber officinale on some biochemical parameters and cytogenic analysis in lead-induced toxicity in experimental rats. Toxicology Mechanisms and Methods 2019, 29, 255-262, https://doi.org/10.1080/15376516.2018.1558321.

17. Ajiboye, B.O.; Oyinloye, B.E.; Essien, P.E.; Onikanni, S.A.; Ojo, O.A.; Kappo, A.P. Ameliorative potential of Sterculia tragacantha aqueous extract on renal gene expression and biochemical parameters in streptozotocin-induced diabetic rats. Journal of Pharmaceutical Investigation 2020, 1-11, https://doi.org/10.1007/s40005-020-00506-8.

18. Ojo, O.A.; Ojo, A.B.; Ajiboye, B.O.; Imiere, O.D.; Oyinloye, B.E. Antihyperlipidemic Activities and Hematological Properties of Ethanol Extract of Blighia Sapida Koenig Bark in Alloxan-Induced Diabetic Rats. Serbian Journal of Experimental and Clinical Research 2020, 21, 11-17, https://doi.org/10.2478/SJECR-2018-0042.

19. Ojo, O.A.; Afon, A.A.; Ojo, A.B.; Ajiboye, B.O.; Okesola, M.A.; Aruleba, R.T.; Adekiya, T.A.; Oyinloye, B.E. Spondias mombim L. (Anacardiaceae): Chemical fingerprints, inhibitory activities, and molecular docking on key enzymes relevant to erectile dysfunction and Alzheimer's diseases. Journal of Food Biochemistry 2019, 43, https://doi.org/10.1111/jfbc.12772.

20. Crichton, M.; Marshall, S.; Marx, W.; McCarthy, A.L.; Isenring, E. Efficacy of ginger (Zingiber officinale) in ameliorating chemotherapy-induced nausea and vomiting and chemotherapy-related outcomes: A systematic review update and meta-analysis.J. Acad. Nutr. Diet. 2019, 119, 2055-2068, https://doi.org/10.1016/j.jand.2019.06.009.

21. Amos, P.O.; Mignouna, H.D.; Thottappilly, G. Genetic fingerprinting and phylogenetic diversity of isolates of Staphylococcus aureus from Nigeria. African Journal of Biotechnology. African Journal of Biotechnology 2003, 2, 246-250, https://doi.org/10.5897/AJB2003.000-1051.

22. Sere, Y.; Onasanya, A.; Akator, K.; Afolabi, A.; Abo, M.E. Serological Differentiation Indices and Phylogenetic Analysis of Rice Yellow Mottle Virus Isolates in Cote d'Ivoire. Int J Biol Sc 2007, 7, 11471154, https://doi.org/10.3923/jbs.2007.1147.1154.

23. Obafemi, T.O.; Onasanya, A.; Adeoye, A.; Falode, J.A.; Daniel, D.J.; Irefo, E.F.; Ojo, O.A.; Fadaka, A.; Afolabi, O.B.; Awe, J.O.; Omiyale, B.O. Protective effect of methanolic and flavonoid-rich leaf extracts of Synsepalum dulcificum (Danielli) on lead-acetate-induced toxicity in Wistar albino rats. Journal of Applied Pharmaceutical Science 2019, 9, 065-072, https://doi.org/10.7324/JAPS.2019.90508.

24. Abdel-Diam, M.M.; Samak, D.H.; El-Sayed, Y.S.; Aleya, L.; Alarifi, S.; Alkahtani, S. Curcumin and quercetin synergistically attenuate subacute diazinon-induced inflammation and oxidative neurohepatic damage, and acetylcholinesterase inhibition in albino rats. Environmental Science and Pollution Research 2019, 26, 3659-3665, https://doi.org/10.1007/s11356-018-3907-9.

25. Abdullaev, S.; Gubina, N.; Bulanova, T.; Gaziev, A. Assessment of Nuclear and Mitochondrial DNA, Expression of Mitochondria-Related Genes in Different Brain Regions in Rats after Whole-Body X-ray Irradiation. International Journal of Molecular Sciences 2020, 21, https://doi.org/10.3390/ijms21041196.

26. Omar, W.A.; Zaghloul, K.H.; Abdel-Khalek, A.A.; Abo-Hegab, S. Genotoxic effects of metal pollution in two fish species, Oreochromis niloticus and Mugil cephalus, from highly degraded aquatic habitats. Mutation research 2012, 746, 7-14, https://doi.org/10.1016/j.mrgentox.2012.01.013.

27. Osman, A.G.M.; Abuel-Fadl, K.Y.; Kloas, W. In situ evaluation of the genotoxic potential of the river Nile: II. Detection of DNA strand-breakage and apoptosis in Oreochromis niloticus niloticus (Linnaeus, 1758) and Clarias gariepinus (Burchell, 1822). Mutation Research/Genetic Toxicology and Environmental Mutagenesis 2012, 747, 14-21, https://doi.org/10.1016/j.mrgentox.2012.02.013.

28. Noel, S.; Rath, S.K. Randomly amplified polymorphic DNA as a tool for genotoxicity: an assessment. Toxicology and Industrial Health 2006, 22, 267-275, https://doi.org/10.1191/0748233706th267oa.

29. Atienzar, F.A.; Jha, A.N. The random amplified polymorphic DNA (RAPD) assay and related techniques applied to genotoxicity and carcinogenesis studies: A critical review. Mutation Research/Reviews in Mutation Research 2006, 613, 76-102, https://doi.org/10.1016/j.mrrev.2006.06.001. 